\title{
The Green Building as a Medium for Environmental Education
}

\author{
LAURA COLE
}

Volume 1, Fall 2013

DOI: http://dx.doi.org/10.3998/mjs.12333712.0001.012

\section{ABSTRACT}

As of 2012, green-building construction was among the fastest-growing industries in the United States. Despite accelerations in green-building technologies over the last three decades and the proliferation of green square footage across the country, the field has largely remained within the narrow confines of industry expertise. The broader public, even those who use green buildings daily, have few opportunities to engage with and learn about them. This lack of public green-building education is problematic, as all Americans are building users, and many will own, construct, and maintain homes throughout their lives. As the public is increasingly presented with opportunities to use public green buildings, there is a need to invite building users into the environmental story of the building and its day-to-day operations. Ultimately, failing to do so could come at a cost to both the building's performance and the enrichment of the user. One response to these challenges is the use of public green buildings as a medium for environmental education, involving users in the performance of the building. While these buildings represent exciting new directions for the current green-building movement, the evidence base for green buildings that teach is still lacking. As projects become reality, there is a parallel need for social research to evaluate outcomes and guide best practices for designing green buildings that contribute to environmental education. This is a research agenda well worth pursuing. In the last two decades, the modern green-building movement has catalyzed over 2 billion square feet of commercial green projects. ${ }^{1}$ As this number grows, each new square foot could be a missed opportunity to connect architecture to public green-building education.

1. http://new.usgbc.org/articles/leed-certified-building-stock-swells-two-billion-square-feet-worldwide 
Introduction

In the United States, buildings contribute to nearly $50 \%$ of the total carbon emissions released into the atmosphere, use nearly $70 \%$ of all electricity produced, and flush 5 billion gallons of potable water through toilets daily (United States Green Building Council, 2009; Yudelson, 2008). Addressing resource and material flows through buildings is an essential part of moving toward an ecologically sane future, but the challenge is not only technical. Green buildings emerge within and are integrated into existing social systems, and it is these systems that arguably drive the innovation and ultimate success of each new green building. In current greenbuilding design and construction, however, projects often fail to engage the broader public, since the public is not often involved in the design process and may be unable to recognize how a green building is different from a conventional building. How then can green-building professionals educate and involve the public in the ongoing experiment of building green?

Fortunately, green buildings can be designed—and are being designed-explicitly with environmental education in mind. In the realm of school architecture, the concept of combining architecture and environmental education results in a school building that is variously referred to as a "teaching tool" or "3-dimensional textbook" for environmental issues (Nair \& Fielding, 2005; Taylor, 1993; United States Green Building Council, 2008). In the absence of a succinct name, I use the term "Teaching Green Building" to refer to buildings intended to promote environmental education. Green buildings contain curricula, both hidden and explicit, and underline the profound story buildings tell about how we treat each other and the ecosystems that sustain us (Orr, 2004). Teaching Green Building projects push our conceptualization of green buildings beyond a viewpoint centered on green technologies, which suggests that green buildings can be vehicles to visualize sustainability (Seibold-Bultmann, 2007), draft new behavioral norms, and suggest increasingly thoughtful ways of using the earth's resources in our day-to-day lives.

The Adam Joseph Lewis Environmental Center at Oberlin College (Figure 1) is a prominent example of the Teaching Green Building in practice (Orr, 2006). This campus building has numerous features that attempt to engage the building visitor in ways both overt and subtle. The most explicit include informational signs that describe the building's design and a touchscreen monitor that displays real-time building energy performance information. Other features solicit visitor attention through their size or novelty, such as the native plantings within an otherwise conventional university landscape or the sizeable greenhouse that hosts tropical plants 

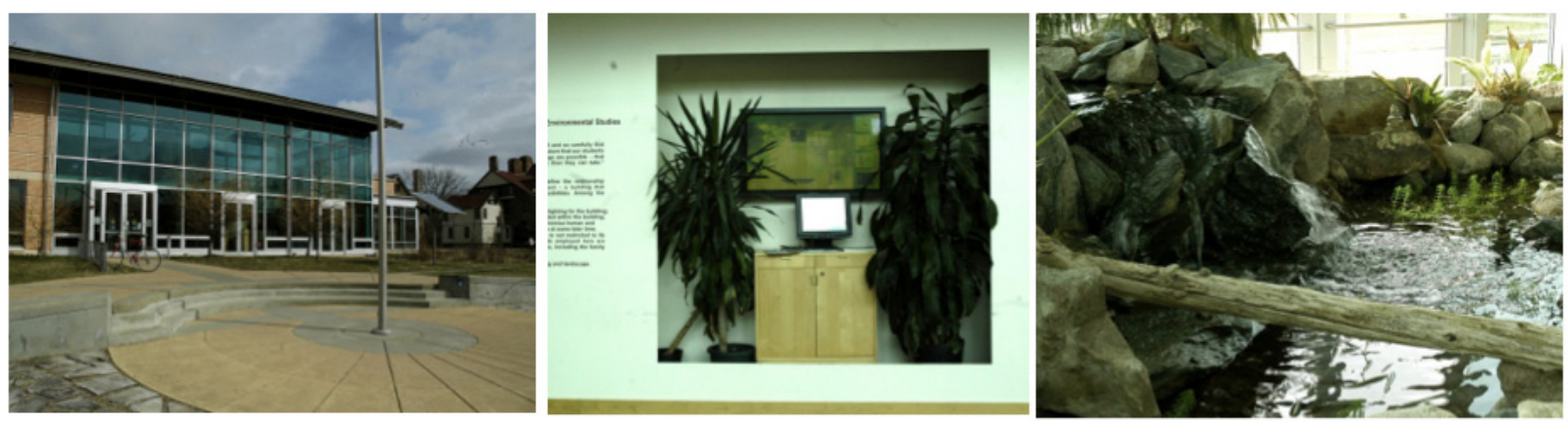

Figure 1: Images of the Adam Joseph Lewis Environmental Center at Oberlin College (photos by author).

used in the water recycling system. The more subtle communications within the building are those that offer aesthetic experiences designed to connect the visitor to nature. One of the most striking sensations is the sound of water heard upon walking into the building. A pleasing arrangement of stones in the corner of the lobby hosts a small fountain, whose contents echo throughout public spaces in the building. Still more intriguing is this fountain's connection to the solar panels outside. The fountain gushes water on a sunny day and slows to a trickle under cloud cover. This trickle is one way the structure is connected to the immediate environment and offers an understated cue to the building occupants that the weather may be changing. In one move, this art-piece fountain advertises alternative energy and provides white noise, an auditory aesthetic, restorative benefits, and information about current weather conditions. Together with the many other visible green features, it signals that this campus building is not like others.

Buildings like the Environmental Center at Oberlin College are beginning to marry the technical story of the building with the human story, thus creating new ways of thinking about the performance of green buildings. Imagine if, beyond counting gallons and kilowatts saved, we could add measures such as ecological knowledge gained or the number of people empowered to improve their local environments. The Teaching Green Building is the first iteration of a green architecture with such aspirations.

Since the Environmental Center at Oberlin College was built, numerous campus and K-12 school buildings have pursued the Teaching Green Building concept. As of 2009, the predominant green-building rating system, Leadership in Energy and Environmental Design (LEED), offers a credit for designers who employ the green school building as a teaching tool (United States Green Building Council, 
2008), offering further incentive for architects and educators to consider the approach. Well-known exemplars of Teaching Green Buildings at the K-12 level include The Bertschi School in Washington (LEED Gold Certification, 2007; Living Building Challenge Certification, 2011), The Willow School in New Jersey (LEED Gold Certification, 2003; LEED Platinum Certification, 2007), and the Sidwell Friends School in Washington, D.C. (LEED Platinum Certification, 2006). With the adoption of the concept by the predominant green-building rating system and the number of built examples increasing, the use of buildings in environmental education appears to be on the rise.

While the number of green buildings continues to increase, knowledge of how to use these buildings for educational purposes remains stagnant. Increasing the level of social research in Teaching Green Buildings can help. A research program of this type can be greatly informed by methods outside those commonly used in green-building research, a point on which I elaborate in the conclusion.

Given the potential cost of implementation, we also need to consider why such buildings are a worthy pursuit. Consider two aspects of the context in which the Teaching Green Building is emerging: 1) few in-roads currently exist for the public to engage with green-building issues, and 2) even where green buildings exist, users are not often engaged in the environmental story of buildings they use from day to day. The Teaching Green Building offers one compelling response to both of these challenges.

\section{Problem 1: Green-Building Education Is Only for Experts}

We are all life-long consumers of buildings - inhabiting them, owning them, building and maintaining them. Given future uncertainties regarding climate stability, energy availability, and a host of concerns relating to natural resources, there may come a time when building owners can no longer ignore the financial and environmental costs of their buildings (Kunstler, 2005; McKibben, 2011). To argue for broad, public green-building education is to argue for the importance of empowering individuals and communities to increase the resilience of their built environment in the face of environmental change. Citizen action could manifest in many ways, from home improvements to participation in community projects and local governance.

Unfortunately, few of us are privy to even basic lessons about architecture or design, let alone green design. While green-building education opportunities abound 
for professionals (United States Green Building Council, 2012), there are few formal or hands-on opportunities for the public to learn about green-building practices. Fortunate citizens live in places with public green buildings that have outreach programs or enjoy proximity to businesses and non-profits that support green-building do-it-yourself projects. There is a small but notable movement to educate youth, and we are beginning to see green-building lesson plans that can be used by teachers at the K-12 level (Green Education Foundation, 2012). For many citizens, however, access to green building education is limited to non-existent. Even more perplexing is that individuals who use green buildings daily are rarely offered information about the performance of the green-building design they inhabit. As the building square footage of green projects increases, so does the population of green-building users and visitors. The Teaching Green Building, while not a panacea for broad public education, is one potential way to extend green-building education beyond professional boundaries.

\section{Problem 2: Green-Building Design Fails to Engage}

To consider the pedagogy of architecture is to ask how a building engages a visitor both mentally and physically. By asking this question, we necessarily move beyond thinking of the green building as an object and increasingly consider the building as a venue for dynamic socio-cultural activities. Building users are thus an integral part of what it means for a building to be green. In terms used by Guy and Farmer (2001), the underlying logic shifts from a dominantly eco-technic lens to one that is increasingly eco-social or eco-cultural. More than a mere feel-good measure, involving people in the building's environmental performance could be one strategy to achieve high performance when technology has reached its limits (Lorenzen, 2012).

Questions of user engagement constitute new territory for a green-building movement that has - in both practice and research - largely focused on the technical performance of green buildings. This bias manifests in the LEED system for new construction projects, in which only 16 out of 69 credits explicitly address the intent to improve outcomes for human beings (Athens, 2009). Stenberg (2006) further notes the trend in the media surrounding green buildings: "The bias [of trade magazines] towards technical measures and their proclivity toward traditional definitions regarding environmental impacts may lock practitioners into a technocratic logic." Numerous scholars have challenged the limited viewpoint of green buildings as assemblages of technological innovation, noting that there is no one 'true' notion 
of a green building, but a variety of lenses through which we can understand sustainable architecture (Guy \& Farmer, 2001; Stenberg, 2006). These viewpoints can expand beyond technology to include social and cultural questions.

Consider the downsides and the benefits of engaging building users in the performance of a green building. From the outside, it may appear that building users are more likely to contribute to problems rather than solutions. We building users can be clumsy, forgetful, unknowledgeable, and busy. We leave windows open and lights on; we crank up thermostats and miss the trash can. Any facility manager could confirm this set of problematic realities. However, we commonly ignore the role that a supportive environment, one designed to support stewardship inside buildings, can play. In other words, a behavioral problem inside a green building may be more of a design problem than a people problem. Thus, instead of jumping to the conclusion that building occupants do not care or want to help, we can first examine the ways the environment supports or fails to support stewardship activity. Offering clearly designed recycling stations, posting informational signage throughout the building, and generally increasing the convenience of environmentally friendly behaviors are all ways that design can support action. Beyond encouraging environmentally responsible behaviors, a supportive environment is one that attempts to educate and involve people, helping building users gain green-building literacy through engagement with the building.

\section{Green-Building Literacy}

As the Teaching Green Building takes physical shape, there is still much to understand about the opportunities for the people who use these buildings. The concept of "Green-Building Literacy" is one way to understand the success of a Teaching Green Building. The definition of such literacy can build on decades of research on "Ecological Literacy," which is a multi-dimensional set of goals for environmental education (Orr, 1992; UNESCO, 1976, 1977). Green-Building Literacy, like Ecological Literacy, is more than factual knowledge: it involves awareness, attitudes, skills, and participation. It encompasses a broad range of factors that describe a citizen who is sensitive, knowledgeable, and ready to take positive action on environmental problems, particularly those related to green buildings. Green-Building Literacy is not only about personal enrichment; it can also improve one's ability to meaningfully contribute to the performance of the green building itself, meaning that occupant knowledge is not simply abstract nor the behaviors symbolic, but that 
they yield outcomes of environmental significance. A person with a basic level of Green-Building Literacy may understand alternative energy systems, be cognizant of the origins of building materials, and know how to operate windows to optimize the building's ventilation system. User understanding may even scale to the level of the city or region, as building users increasingly understand how the building itself participates in local ecology. Perhaps the ultimate outcome of Green-Building Literacy is translation across buildings, where citizens become advocates for change in their own built environments. Together, the concepts of the "Teaching Green Building" and "Green-Building Literacy" identify exciting new directions for greenbuilding practice and research-a movement that has logical beginnings in school architecture, where compelling real-world examples, such as the Environmental Center building at Oberlin College, can be found.

\section{A New Research Agenda}

While exemplary Teaching Green Building projects are being realized in practice, research about environmental education in these buildings remains sparse. One reason for this could be the newness of the trend in architectural practice; another is that Green-Building Literacy is a difficult outcome to measure. It has many dimensions and is difficult to isolate when there are so many socio-cultural influences on sustainability learning, such as influential role models and the presence of environmentalism in the media. Multi-dimensionality and confounding influences further complicate the ability to "prove" that building design influences educational outcomes, especially compared to more traditional educational research that focuses on formal learning processes such as the impact of a specific curriculum. For this reason, research methods used in informal environmental education and museum studies present promising models, as their tendency toward mixed methods better allows the research process to reflect the messiness of the setting. Such research, based on rigorous assessment of user experiences, can inform the design and construction of Teaching Green Buildings.

Given the significant environmental impact of buildings, their increasing prevalence in modern life, and the lack of public green-building education, the Teaching Green Building is a goal worth pursuing. With green building as one of the fastestgrowing industries in the United States (Plumer, 2012), each new square foot is an opportunity to connect architecture to environmental education. It is important to take these opportunities, and social research can help to guide best practices for 
doing so. Teaching Green Buildings are one approach within an emergent greenbuilding education movement that seeks to engage the public in the important role of buildings in our local ecologies.

\section{References}

Athens, L. 2009. "Green Architecture Benchmarking for Social Issues." News and Society: Environmental Articles. Accessed February 28, 2013. http://ezinearticles.com/?expert=Lucia_Athens.

Green Education Foundation. 2012. "Green Building Program.” Accessed June 27, 2012. http:// www.greeneducationfoundation.org/green-building-program-sub.html.

Guy, S., and G. Farmer. 2001. "Reinterpreting Sustainable Architecture: The Place of Technology." Journal of Architectural Education 54 (3), 140-148. http://dx.doi. org/10.1162/10464880152632451

Kunstler, J. H. 2005. The Long Emergency: Surviving the Converging Catastrophes of the Twenty-first Century. New York: Atlantic Monthly Press.

Lorenzen, J. A. 2012. "Green and Smart: The Co-Construction of Users and Technology." Human Ecology Review 19 (1).

McKibben, B. 2011. Earth: Making a Life on a Tough New Planet. New York: St. Martin's Griffin.

Nair, P., and R. Fielding. 2005. The Language of School Design: Design Patterns for 21st Century Schools. Minneapolis: Designshare, Inc.

Orr, D. W. 1992. Ecological Literacy: Education and the Transition to a Postmodern World. Albany: State University of New York Press.

Orr, D. W. 2004. Earth in Mind: On Education, Environment, and the Human Prospect. Washington, DC: Island Press.

Orr, D. W. 2006. Design on the Edge: The Making of a High-performance Building. Cambridge, MA: MIT Press.

Plumer, B. 2012. "The Top 10 Fastest-growing U.S. Industries." http://www.washingtonpost.com/blogs/ezra-klein/post/the-top-10-fastest-growing-us-industries-hint-think-hotsauce/2012/04/17/gIQAqzZpNT_blog.html.

Seibold-Bultmann, U. 2007. "What Does Sustainability Look Like? Green Architecture as an Aesthetic Proposition.” Interdisciplinary Science Reviews 32 (1): 3-6.

Stenberg, A. 2006. The Social Construction of Green Building: Diachronic and Synchronic Perspectives. Göteborg: Chalmers University of Technology.

Taylor, A. P. 1993. "The Learning Environment as a Three-Dimensional Textbook." Children's Environments 10 (2): 170-179.

UNESCO. 1977. Tbilisi Declaration. Accessed February 28, 2013. http://www.gdrc.org/uem/ee/ tbilisi.html.

UNESCO-UNEP. 1976. “The Belgrade Charter: A Global Framework for Environmental Education." Connect: UNESCO, UNEP Environmental Education Newsletter 1 (1): 1-2.

United States Green Building Council. 2008. "LEED 2009 for Schools New Construction and Major Renovations." Accessed February 28, 2013. http://www.usgbc.org/ShowFile. aspx? DocumentID=5547. 
. 2009. "Introduction to the LEED Rating System." In The Sustainable Urban Development Reader, $2^{\text {nd }}$ ed., edited by Stephen M. Wheeler and Timothy Beatley. London: Routledge, 273-278.

. “2012. U.S. Green Building Council Education.” Accessed September 26, 2012. http:// www.usgbc.org/DisplayPage.aspx?CategoryID=127.

Yudelson, J. 2008. The Green Building Revolution. Washington, DC: Island Press. 